\title{
Väestökysymystä, perhettä ja avioliittoa käsittelevää suomalaista kirjallisuutta vuosina 1950-1952
}

\author{
Luetteloinut Helmi Nykänen.
}

Tähän bibliografiaan, joka muodostaa jatkon Väestöliiton toisessa ja kolmannessa vuosikirjassa ilmestyneille, sisältyy paitsi Suomessa painettuja itsenäisiä julkaisuja täällä ilmestyneiden tärkeimpien aikakauslehtien sekä kokoomateosten kirjoituksia, mutta ei sanomalehtiartikkeleita eikä kotimaisille kielille käännettyä kirjallisuutta. Saman kirjoittajan eri yhteyksissä julkaisemista samanlaisista kirjoituksista on vain yksi otettu huomioon.

Alho, K. O., Lapsilisäjärjestelmästämme. Kansamme talous 1951, s. 185.

Allardt, Erik, Att förutsäga den äktenskapliga anpassningen. Barn, familj, samhälle. Helsingfors 1952 . Ss. 70-78.

- Miljöbetingade differenser i skilsmässofrekvensen. Olika normsystems och andra sociala faktorers inverkan pã skilsmässofrekvenserna i Finland 18911950. (Akad. avh.) Helsingfors 1952. 203 s.

Aminoff, Torsten G., Familjepolitikens motivering. Barn, familj, samhälle. Helsingfors 1952. Ss. 7-19.

Anttila, Toivo, Rakentamisen laajuus v. 1950 ja sen johdosta tehtäviä arviointeja. Asutustoiminnan aikakauslehti 1950:4, ss. 8-9.

Appel, Erik, Den svenskösterbottniska emigrationen. Finsk tidskrift 1952, t. 152 , ss. $1-10$.

- Några synpunkter på den svenskösterbottniska emigrationen från Sverige. Barn, familj, samhälle. Helsingfors 1952. Ss. $110-117$.

Aro, Pirkko, Kodinhoitaja perheen apuna. Tulevaisuus 1952:7, ss. 4-6.

Asuntojen tuotanto kaupungeissa ja kauppaloissa 1951. Sasiaalinen aikakauskirja 1952 , ss. $112-122$.

Aura, Teuvo, Asuntopulan poistaminen nykyisten mahdollisuuksien puitteissa. 
Kansantaloudellinen aikakauskirja 1950 , ss. $308-320$.

Barn, familj, samhälle. Ks. Svenska befolkningsförbundets i Finland publikation 11.

Bonsdorff, Olavi, Zürichin vihreät kaupunginosat. Asuntopolitiikka 1952:4, ss. $6-7$.

Brander, E. \& Niemineva, K., Raskaudenkeskeyttämisaiheista maaseutusairaaloissamme. Duodecim 1950, ss. $343-348$.

Bruun, Elsa \& Stâhlberg, Aune, Lastensiirrot Ruotsiin vuosina 1941-48. Sosiaalinen aikakauskirja 1950 , ss. $1-10$.

Cavonius, Gösta, Befolkningsutvecklingen och skolväsendet. Barn, familj, samhälle. Helsingfors 1952 . Ss. $49-54$.

Christiansen, Arne, Tanskan lapsilisälaki. Sosiaalinen aikakauskirja 1950, ss. $164-165$.

- Tanskan nuorison asunto-olot. Sosiaalinen aikakauskirja 1950, ss. 74-75.

Ekholm, E., Kunnanlääkäri ja avioliittoneuvonta. Avioliitto ja lääkäri 1950:3. ss. $1-3$.

Elfvengren, Elisabeth, Industrins kvinnliga arbetskraft. Helsingfors 1951. 95 s. Ks. Wahlbeck, Lars \& Paukkunen, Leo \& Elfvengren, Elisabeth, Den ekonomiska utvecklingen inom industriella storföretag 1947-1950. (Ekonomiskautredningsbyrān, ser. B:2.)

- Osapäivätyöstä ja sen käytöstä. Teollisuuslehti 1951, ss. $370-371,374$.

Englannin avioliittoneuvonnan yleiset periaatteet. Avioliitto ja lääkäri 1950:4, s. 4.

Englund, Kaj, Millainen on perheasunto. Tehostaja 1952:3, ss. 13-21.

Erkkilä, Sven, Eräs sosiaalinen probleema. Rikokset alkavaa elämää kohtaan. Lapsi ja nuoriso $1951: 9$, ss. $25-28$.

- Hygienian ja sosiaalilääketieteen näköaloja. Duodecim 1951, ss. $291-303$.

- Lastenneuvolatoimintaa laajennettava. Suomen lääkärilehti 1951, ss. 243-250.

- Miespuolisista sikiönlähdettäjistä. Duodecim 1952, ss. 402-419.

- Sikiönlähdettäjistä ja sikiönlähdetitämisen rangaistavuudesta de lege ferenda. Duodecim 1952, ss. $183-203$.

- Steriloinnista ja sen yhteiskunnallisesta merkityksestä. Suomen lääkärilehti 1951 , ss. $833-842$.

Eskola, Aarne, Kokonaisohjelma asiantuntijoiden käsiteltävänä. (Asuntopoliittista kokonaisohjelmaa koskeva keskustelu.) Asuntopolitiikka 1951:1, ss. 4-5.

Fieandt, Kai von, Minkälainen on sopusuhtainen koti lapsen kannalta. Lapsi ja nuoriso $1952: 4$, ss. $14-17$.

Flodin, O., Aluesuunnittelusta. Maalaiskunta 1950, ss. $364-366$.

Forsberg, Karl-Erik, Befolkningsstatistiska specialundersökningar. Jorma Hyppölä - Aarre Tunkelo - Leo Törnqvist: Beräkningar rörande Finlands befolkning, dess reproduktion och framtida utveckling. Ekonomiska samfundets tidskrift 1950 , ss. $110-112$. 
Den svenska befolkningen i Helsingfors. Barn, familj, samhälle. Helsingfors 1952. Ss. $99-109$.

- Ett minoritetsproblem i Helsingfors. Finsk tidskrift 1952, t. 151, ss. 138-141.

- Strukturolikheter inom befolkningen i olika delar av Helsingfors. Finsk tidskrift 1950 , t. 147 , ss. $6-14$.

Fougstedt, Gunnar, Barnbidragen och barnfamiljernas skattebörda. Barn, familj, samhälle. Helsingfors 1952. Ss. 26-33.

- Befolkningsfaktorn i samhällsmekanismen. Hannes Hyrenius: Befolkning och samhälle. Ekonomiska samfundets tidskrift 1952, ss. $188-190$.

- Finlands svenska befolkning åren 1936-1945. En demografisk undersökning. (Akad. avh.) Helsingfors 1951. 248 s. (Bidrag till kännedom af Finlands natur och folk 95:2.)

- Om demografiska undersäkningar av nationella grupper. Ekonomiska samfundets tidskrift 1952 , ss. $150-156$.

- Synpunkter pā inkomstbeskattningen. Ekonomiska samfundets tidskrift 1952, ss. $78-92$.

- Väestönmuutokset vuonna 1948. Tilastokatsauksia 1950:3-4, ss. 28-37.

- Väestönmuutokset vuonna 1949. Tilastokatsauksia 1950: 11-12, ss, $31-40$.

- Väestönmuutokset vuonna 1950. THlastokatsauksia 1951: 9-10, ss. 33-42.

Glyn-Jones, Muriel, "Eheä koti on jokaisen lapsen oikeus". Lapsi ja nuoriso 1952: 11 , ss. $5-7$.

Gripenberg, Ole, Asumistaso meillä ja Tanskassa. Kansamme talous 1952, s. 135.

Gutin, E. G. \& Niemi, Turo, Avioliitto. Opaskirja Suomen kodeille. 3. p. Helsinki 1950. $247 \mathrm{~s}$.

Haakana, Saimi, Väestöpoliittisten avustusten jakautumisesta maassamme. Huoltaja 1952 , ss. $382-384$.

Haikala, Eino, Kärpäsestä härkänen eli muutamia mietteitä liikakansoituskysymyksestä. Suomen osuustoimintalehti 1951, ss. 6-10.

Halminen, U. V. Silrtolaisuus vv. $1949-1950$. Tilastokatsauksia 1951: 5-6.

Hannus, Arno, Perhekustannukset tuloverotuksessa Rlanskassa omaksutun kulutusyksikköjärjestelmän mukaan. Lakimies 1951, ss. 594-604.

Heino, Arvo \& Niemineva, Kalevi, Huomioita periytyvistä somaattisista sairauksista ja niliden esitintymisestä Suomessa. Duodecim 1950, ss. 458-477.

Henriksson, Weio, Arava-lănen. Finsk tidskrifit 1950, t. 147, ss. 145-153.

Hertzen, Heikki von, Asuntopoliittinen kokonaisohjelma. Asuntopolitikka 1950: 3 , ss. $3-4$.

- Asuntopolitilkkamme "puuttuva rengas". Asuntopolitilkka-1951: 1, s. 3.

- Emme osaa rakentaa kaupunkeja. Suomen punainen risti 1951 , ss. $38-40$.

- Ihanteellinen perheasunto nykyaikaisen asuntopolitilkan päätavoitteita. Lapsi ja nuoriso $1950: 9$, ss. $22-24$.

- Keskustelua lapsilisäjärjestelmästä. Kansamme talous 1952, ss. 616-617.

- Valtakunnansuunnittelu ja asuntokysymys. Asuntopolitiikka 195r: 4, ss. 3-4. 
Heurlin, Lauri O. af, Barn, familj, samhälle. Kansantaloudellinen aikakauskirja 1952, ss. $216-217$.

Hieta, Irja, Kotisisar tuo avun kotiin. Lapsi ja nuoriso 1952: 4, ss. 24-25.

Huhtinen, Anja, Connecticutin valtion äitiyshuollosta. Kätilölehti 1950, ss. 366370.

— "Isäkurssit" meilläkin tarpeen. Avioliitto ja lääkäri 1952: 1, ss. 1-2.

- .. jotta lapsi syntyisi terveenä. Lapsi ja nuoriso 1952: 9, ss. 8-10.

- Kunnankätilön tehtävät äitiyshuollossa. Maalaiskunta 1950, ss. 269-271.

Hyppölä, Jorma, Ammatti- ja elinkeinotilastomme perusteet vuoden 1950 väestölaskennassa. [2.]. Tilastokatsauksia $1951: 5-6$, ss. $34-36$. [1.] Ks. Strömmer, Aarno.

Hyppölä, Jorma \& Tunkelo, Aarre \& Törnqvist, Leo, Suomen väestöä, sen uusiutumista ja tulevaa kehitystä koskevia laskelmia. Helsinki 1950. 142 s. (Tilastollisia tiedonantoja 38.)

Hälström, Erik af, Den österbottniska emigrationen. Finsk tidskrift 1950 , t. 148, ss. $209-216$.

Ingman, Ove, Lääkäri ja sosiaalineuvolaan lähetettävät potilaat. Avioliitto ja lääkäri 1951: 4 , ss. 1-3.

Isän kalenteri 1951, 1952 ja 1953. Julk. Väestöliitto. Helsinki 1950, 1951 ja 1952. Jaatinen, Stig, Finlands befolkningstyngdpunkt. Ekonomiska samfundets tidskrift 1952, ss. $168-172$.

Jalavisto, Eeva, Ihmisen biologisesta iästä ja elämän ennusteesta. Duodecim 1952 , ss. $1-12$.

- Ihmisen pitkäikäisyyteen vaikuttavista tekijöistä. Suomalainen Suomi 1950, Ss. $6-13$.

- Vanhempien iän vaikutuksesta lasten elinikään. Lapsi ja nuoriso $1950: 3$, ss. 5-9.

— Väestön vanheneminen lääketieteellisenä ja sosiaalisena kysymyksenä. Huoltaja 1951 , ss. $327-335$.

Jalkanen, Risto, Huomioita Kainuun monisynnyttäjistä. Avioliitto ja lääkäri 1951: 3 , ss. $1-3$.

Jalo, Margit, Huoltotoiminta tilaston valossa vv. 1940-1950. Maalaiskunta 1950, ss. $429-432$.

— Lapsilisät vuonnà 1951. Kirj. M. J-0. Huoltaja 1952, ss. $419-420$.

- Lastenvaatteet perhelisän ensisijaisena käyttömuotona. Kirj. M. J-o. Huoltaja 1952 , ss. $536-537$.

- Tilastoa lastensiirroista Ruotsin vuosina 1941-46. Sosiaalinen aikakauskirja 1950 , ss. $107-116$.

- Aitiysavustukset vuonna 1950. Kirj. M. J-o. Huoltaja 1952, ss. 174.

Jarle, P.-O., Miten selviytyä asuntopulasta. Kansamme talous 1952, ss. $646-647$, 650.

Joensuu, Matti, Ajatuksia sielunhoitajan asenteesta. Vartija 1952, ss. 108-111. - Avioliitto tarvitsee neuvontaa. Huoltaja 1952, ss. $43-47$. 
- Avioliittoneuvonnan käytäntöä. Huoltaja 1952, ss. 87-90.

- Avoimia kysymyksiä nuorten kasvattamisesta avioliittoon. Lapsi ja nuoriso 1952: 10 , ss. $20-22$.

- Kun avioliitto ajautuu karille. Suomen punainen risti 1951, ss. 106-108.

- Piirteitä Englannin avioliittoneuvonnasta. Vartija 1952, ss. $34-37$.

Johansson, Carl Johan, Hur många barn ska vi ha? Avioliitto ja lääkäri 1952: 2, ss. $3-5$.

Junnila, T., Keskustelua lapsilisäjärjestelmästä. Kansamme talous 1952, ss. 6176 i's.

Jutikkala, Eino, Edellisen luettua. Suomalainen Suomi 1952, ss. 160-161. Ks. myös Saksa, P. J.

- Kuinka suuri on Suomen maatalousväestö? Suomalainen Suomi 1951, ss. $518-520$.

- Reino Lento, Maassamuutto ja siihen vaikuttaneet tekijät Suomessa vuosina 1878-1939. Kansantaloudellinen aikakauskirja 1951, ss. $160-166$.

- Yli kolmekymmentä miljoonaa vuodessa. Suomalainen Suomi 1951, ss. 475477.

Kahanpää, K. H., Väestöliitto, Väestönkehityksen ja avioliiton ongelmia. Kansantaloudellinen aikakauskirja 1951, ss. 244-245.

- Väestönmuutokset vuonna 1951. Tilastokatsauksia 1952: 9-10, ss. 40-47.

Kaila, Hellevi, Wien rakentaa lapsilleen. Lapsi ja nuoriso 1950: 10, ss. $7-8$.

Kajala, Olavi, Kokonaisohjelma asiantuntijoiden käsiteltävänä. (Asuntopoliittista kokonaisohjelmaa koskeva keskustelu). Asuntopolitilkka 1951: 1, s. 5.

Kansainvälinen perhe- ja väestökonferenssi Suomessa. Sosiaalinen aikakauskirja 1950 , ss. $380-382$.

Kaprio, Leo, Avioliittoneuvolatoiminta maassamme. Avioliitto ja lääkäri 1950: 1, ss. $2-4$.

Kaprio, Leo \& Niemineva, Kalevi, Keskenmenokysymyksen taustaa. Väestöliiton vuosikirja 3. Helsinki 1951 . Ss. $145-157$.

Kaprio, Leo \& Niemineva, Kalevi, Sukupuolielämää koskevista ryhmätutkimuksista. Aviolii.tto ja lääkäri 1951: 2, ss. 11'-13.

Karsten, Anitra, Intryck från USA. Geron 2-3. Helsinki 1951. Ss. 23-30.

Kinnunen, Olavi \& Kauppinen, Martti, Näkökohtia Helsingin Naistenklinikan poliklinikassa hoidetuista keskenmenoista. Duodecim 1951, ss. 745-756.

Klami, Aili, Miten kannamme vastuun äidin sijaisina? Lapsi ja nuoriso 1952:6, ss. $10-11$.

Klintskog, Erik, Indikationer och komplikationer vid legal abort i Sverige. Avioliitto ja lääkäri $1952: 4$, ss. $1-4$.

Kodinperustamislainatoiminta v. 1950. Huoltaja 1951, ss. $272-274$.

Koiso-Kanttila, Erkki, Lastenhuolto ja asemakaavoitus. Lapsi ja nuoriso 1952: 78 , ss. $8-11$.

Komiteanmietintö 1951:9. Maaseudun asunto-olojen parantamiskomitean mie- 
tintö. Ehdałus maaseudun asunto-olojen parantamislaiksi ja silhen liittyväksi lainsäädännöksi. Helsinki 1951. $78 \mathrm{~s}$.

- 1952: 11. Vanhustenhuoltokomitean mietintö. Helsinki $1952.100 \mathrm{~s}$.

Koskikallio, Margit, Naimattoman äidin edellytykset lapsensa kasvattajana. Lapsi ja nuoriso 1951: 5, ss. $20-26$.

- Yhteiskunnan suhtautumisesta aviottomaan äitiyteen. Lapsi ja nuoriso 1950, ss. $22-24$.

Kotilainen, Niilo, Terve kotielämä sosiaalihuollon tavoitteeksi. Huoltaja 1952, ss. 491- 492.

Lahdensuu, Sakari, Lastenneuvolatoiminnasta. Suomen lääkärilehti 1950 , ss. 860 -870 .

Lappalainen, Veijo, Varattomien ja vähävaraisten perheenäitien lomanvieton järjestäminen. Sosiaalinen aikakauskirja 1950, ss. $257-264$.

- Aitiysavustuksen saaminen. Huoltaja 1951, ss. 143-144.

Lapsilisät v. 1949. Sosiaalinen aikakauskirja 1950, ss. 213-215.

— v. 1950. Sosiaalinen aikakauskirja 1951, ss. $256-259$.

- v. 1951. Sosiaalinen aikakauskirja 1952 , ss. $219-221$.

Lehti, Helmer, Asuntokurjuus meillä ja muualla. Kansamme talous 1952, ss. 412 $-413$.

Leikkola, A. H., Miehen steriliydestä. Suomen lääkärilehti 1951, ss. 177-185.

Leivo-Larsson, Tyyne, Aiti on ansiotyössä - kuka hoitaa lapset? Lapsi ja nuoriso $1952: 3$, ss. $4-7$.

Lento, Reino, Demographic Yearbook - Annuaire Démographique 1948. - Jan Wallander, Flykten från skogsbygden. Väestöliiton vuosikirja 3. Helsinki 1951. Ss. $210-214$.

- Inrikesflyttningen i Finland 1878-1939. Genmäle till professor Helmer Smeds, Ekonomiska samfundets tidskrift 1952, ss. $173-177$.

- Maassamuutto ja silhen vaikuttaneet tekijät Suomessa vuosina 1878-1939. (English summary). [Väitösk.] Helsinki 1951. 251 s. (Väestöpoliittisen tutkimuslaitoksen julkaisuja, sarja A: 5).

- Muuttoliikkeen suunnasta eräissä Varsinais-Suomen kunnissa vuosina 19211945. Väestöliiton vuosikirja 3. Helsinki 1951. Ss. 85-102.

- Perhesuhteiden huomioon otto Ranskan tuloverotuksessa. Väestöliiton vuosikirja 3. Helsinki 1951. Ss. 174-178.

- Syntyneisyyden aleneminen ja sen alueelliset eroavuudet Suomessa vv. 19111940. Väestöliiton vuosikirja 3. Helsinki 1951. Ss. $17-36$.

- Väestön vanheneminen sekä sen taloudelliset ja sosiaaliset seuraukset. Väestöliiton vuosikirja 3 . Helsinki 1951 . Ss. $59-84$.

Lähdeoja, Eino, Eräitä ajankohtaisia kysymyksiä asuntorakennustoiminnan kehittämisestä maaseudulla. Maalaiskunta 1951 , ss. $544-545$.

- Tilastollinen selvitys maaseudun asunto-oloista vuonna 1950. 1-2. Asutustoiminnan aikakauslehti $1951: 2$, ss. $10-12 ; 1951: 3$, ss. $8-12$. 
Mannio, Niilo, Sosiaalimenojen kehitys vilme kymmenvuotiskautena. Kansantaloudellinen aikakauskirja 1950, ss. 142-162.

- Sosiaaliturvamme kehittäminen. Soslaalinen aikakauskirja 1952, ss. $451-460$.

Merikoski, V., Papiston erioikeudet ja yleisen väestörekisterin aikaansaaminen. Lakimies 1950, ss. 701-708.

Meurman, Otto-I., Asumasolu ja asumalähiö. Asuntopolitiikka 1'350:1, ss. 6-7.

- Asuntoalueiden suunnittelusta Englannissa. Asuntopolitilkka 1951: 2, ss. 4-5.

- Ihmisen rakennukset ja kätten jäljet maisemassa. Maalaiskunta 1951, ss. 380 -382 .

- Kaupunkiasutus jaettava erillisiksi asumalähiöiksi. Talouselämä 1951, ss. 162163.

- Kokonaisohjelma asiantuntijoiden käsiteltävänä. (Asuntopoliittista kokonaisohjelmaa koskeva keskustelu.) Asuntopolitiikka 1951: 1, ss. 5-6.

- Maaseudun asemakaavoitus. Maalaiskunta 1950, ss. 220-223.

- Uuden asemakaavalakiehdotuksen puntarointia. Asuntopolitikka 1951:3, ss. $6-8$.

Modeen, Gunnar, Barnfamiljernas bostadsstandard och hyresutgifter. Barn, familj, samhälle. Helsingfors 1952. Ss. $20-33$.

Moilanen, Kaapro, Siirtolaisuuskysymyksemme. Kansamme talous 1952, ss. 244 246.

Murén, Edvard, Kunnan oikeus avustaa yksityistä asunnonrakentamistoimintaa. Suomen kunnallislehti $1951: 8$, ss. $4-7,22-23$.

Mäkinen-Ollinen, Aune, Aidit ja ansiotyö. Lapsi ja nuoriso 1952: 4, ss. 26-28.

Nieminen, Armas, Avioerojen yleistymisen syistä. Suomalainen Suomi 1950, ss. $527-530$.

- Katsaus Väestöliiton toimintaan viisivuotiskautena 1946-1950. Väestöliiton vuosikirja 3. Helsinki 1951 . Ss. $179-198$.

- Lapsilisien jakaantuminen eri yhteiskuntaryhmien ja maan eri osien kesken. Kansamme talous 1952 , ss. $131-132$.

- Seksuaali- ja perhesosiologista ulkomaista kirjallisuutta 1940-luvulla. Väestölititon vuosikirja 3. Helsinki 1951. Ss. 199-209.

- Seksuaalikysymys sosiaalipoliittisena ongelmana. Suomalainen Suomi 1952, ss. $15-18$.

- Suomen väestön uusiutumiskyvyn ja aviollisen hedelmällisyyden alueellisista eroavuuksista vuosina 1938-1939. Väestöliiton vuosikirja 3. Helsinki 1951. Ss. $37-58$.

- Taistelu sukupuolimoraalista. Avioliitto- ja seksuaalikysymyksiä suomalaisen hengenelämän ja yhteiskunnan murroksessa sääty-yhteiskunnan ajoilta 1910luvulle. (English summary.) [Väitösk.] Porvoo-Helsinki 1951. $410 \mathrm{~s}$. (Väestöpolittisen tutkimuslaitoksen julkaisuja, sarja $A: 6$ ).

- Väestön uusiutumiskyvystä eri maissa. Väestöliiton vuosikirja 3 . Helsinki 1951. Ss. $161-163$. 
Niemineva, Kalevi, Keskenmenojen määrästä Suomessa. Lisämietteitä trien Rouhunkosken ja Oljen suorittamista tutkimuksista. Avioliitto ja lääkäri 1952: 4, s. 14 .

- Näköaloja avartavaa. Armas Nieminen: "Taistelu sukupuolimoraalista". Avioliitto ja lääkäri $1952: 2$, ss. $10-12$.

- Piirteitä avioliittoneuvoloiden kehityksestä Suomessa. Katsaus Väestöliiton avioliittoneuvoloiden toimintaan vuonna 1950 . Väestöliiton vuosikirja 3. Helsinki 1951. Ss. $119-132$.

- Terveydellisen avioliittoneuvonnan tulevaisuudennäköaloja. Huoltaja 1950, ss. $53-55$.

- Väestöliitto kymmenvuotias. Avioliitto ja lääkäri 1951:2, ss. $1-3$.

Niemineva, Kalevi \& Timonen, Sakari, Näkökohtia sosiaalineuvolan käytännöllisestä järjestelystä. Duodecim 1950 , ss. $216-220$.

Niemineva, Kalevi \& Ylinen, Olli, Huomioita raskaudenkeskeyttämislakimme vaikutuksista. Suomen lääkärilehti 1952, ss. 177-191.

Nyberg, Bertel, Uudenaikainen lapsihotelli Helsinkiin. Huoltaja 1952, ss. $148-149$. Nykänen, Helmi, Väestökysymystä, perhettä ja avioliittoa käsittelevää suomalaista kirjallisuutta vuosina 1948-1949. Väestöliiton vuosikirja 3. Helsinki 1951. Ss. $215-225$.

Odottamaton raskaus - miten selviän vaikeuksistani? Ohjeita yksinäisille äideille. [Julk. Väestöliitto.] Helsinki 1952. $24 \mathrm{~s}$.

Odottamaton raskaus - miten selviän vaikeuksistani? Opas aviovaimoille. [Julk. Väestöliitto.] Helsinki 1952. $24 \mathrm{~s}$.

Ojala, O., Viime vuosien siirtolaisuus Suomesta. Sosiaalinen aikakauskirja 1952, ss. $393-396$.

Olki, Mikko, Avioliittoneuvontaa Länsi-Saksassa. Avioliitto ja lääkäri 1¡52: 3, ss. 8-9.

- Perinnöllisyysneuvonta alkaa syyskuun 1 p:nä. Aviolittto ja lääkäri 1951:2, ss. $7-9$.

Paloheimo, Martti, Odottavan äidin mielenterveydenhoidosta Lapin äitejä silmalläpitäen. Kätilölehili 1952, ss. 303-312.

Parland, Oscar, Intryck från äktenskapsrådgivningen i Schweitz. Avioliitto ja lääkäri 1951: 4, ss. 11-12.

Pautola, Lauri, Kodin velvollisuudet sukupuolikasvatuksessa. Lapsi ja nuoriso 195i: 1 , ss. $22-25$.

Pentikäinen, $T$., Valtion viran- ja toimenhaltijain perhe-eläkevakuutus. Sosiaalinen aikakauskirja 1952 , ss. $183-186$.

Perhekasvatusta tehostamaan. Esitelmiä nuorisolle sukupuolikysymyksestä. [2. p.] $\mathrm{H}: \mathrm{ki}$ 1952. $121 \mathrm{~s}$.

Perhelisät v. 1953 . Sosiaalinen aikakauskirja 1952, ss. $303-305$.

Peräläinen, A., Kulutusyksikköjärjestelmä verotuksessa. Kansamme talous 1952, ss. $619-620$. 
Pitkänen, Heikki, Aitiyshuollon viimeaikaisesta kehityksestä maassamme. Suomen lääkärilehti 1950 , ss. $483-526$.

- Aitiyshuolto ja syntyvyyden säännöstely. Avioliitto ja lääkäri 1951: 1, ss. 1-2.

- Aitiysneuvoloissa annettavista ohjeistą. Suomen lääkärilehti 1951, ss. 255-264.

Pitsinki, Kaarlo, Koti kaikille - kuinka ja milloin. Sosialistinen aikakauslehti 1951 , ss. $190-192$.

Procopé, Victor, Den förflyttade befolkningens problem. Axel von Gadolin: Das Flüchtlingsproblem in Finnland. Ekonomiska samfundets tidskrift 1952, ss. 111-117.

- Finlands lösning av de förflyttades problem alltjämt i blickpunkten. Ekonomiska samfundets tidskrift 1952, ss. $244-246$.

Pula lastentarhoista ja niiden opettajista. Karttaliite: Päivähuoltolaitosten sijainti vuoden 1948 lopussa Lastensuojelun keskusliitossa suoritetun tutkimuksen mukaan. Lapsi ja nuoriso 1951: 5, ss. $3-5$.

Railo, Maija, Lapsilisäjärjestelmästämme. Kansamme talous 1951, s. 186.

Raitasuo, Kyllikki, Mitä ero lapsesta äidille merkitsee? Lapsi ja nuoriso 1952: 5 , ss. $27,31$.

Raivio, Arvi, Tuomioistuimen päätöksellä puretut avioliitot vuosina 1948,1949 ja 1950. Tilastokatsauksia 1951: $7-8$, ss. $37-41$.

Rautanen, Elina, Entä lastenne elintila? Lapsi ja nuoriso 1951: 3, ss. 20-25.

Rautkari, K., "Kultturellia kvaliteettia" eli Suomen kansa rakentaa. Tehostaja 1950 , ss, $688-692$.

Riihinen, V., Asuntotilanteesta ja asuntotuotannosta. Kansamme talous 1951, ss. $162-163$.

Rouhunkoski, Mauri, Aviolittoneuvolat avun antajina. Terveydenhoitolehti 1951, ss. $4-6$.

- Kätilöiden osuus uuden aborttilain toteuttamisessa. Kätilölehti 1950 , ss. 271278.

- Raskauden laillinen keskeyttäminen. Terveydenhoitolehti 1951, ss. 144-146.

- Sukupuolikasvatus. Lapsi ja nuoriso 1950: 5, ss. 11-14, 32.

- Syntyvyyden säännöstely normaalista poikkeavissa tapauksissa. Avioliitto ja lääkäri 1950: 1, ss. 5-6.

- Syntyvyyden säännöstelyn opas. 3. p. Helsinki 1950. 48 s.

- Terve sukupuolielämä. Terveydenhoitolehti 1951. Ss. 218-221.

Rouhunkoski, Mauri \& Olki, Mikko, Rikollisten raskaudenkeskeytysten aiheuttamista työpäivän menetyksistä. Duodecim 1952, ss. 628-634.

Rouhunkoski, Mauri \& Valvanne, Leena, Sosiaalineuvolan työsaralta. Aviolittto ja lääkäri 1950: 4, ss. $1-3$.

Runeberg, Johan, Psykiatriset indikatiot uuden aborttllain puitteissa. Avioliitto ja lääkäri $1951: 1$, ss. $3-6$.

Saksa, P. J., "Kuinka suuri on Suomen maatalousväestö?" Suomalainen Suomí 1952, ss. $157-160$. 
Salmela-Järvinen, Martta, Yksinäisen äidin ongelmia. Huoltaja 1952, ss. 431$433,448$.

Saloheimo, Aksel, Avioliittoon aikovien neuvonnasta. Avioliitto ja lääkäri 1952: 3 , ss. $1-3$.

- Aitiyskuvasto on ilmestynyt. Avioliitto ja lääkäri 1950: 4, ss. 7-9.

Salomaa, Niilo, Perhelisän suoritusmuodoista. Huoltaja 1951, ss. 95-97.

- Perhelisät v. 1948. Sosiaalinen aikakauskirja 1951, ss. 28-30.

— Perhelisät v. 1949. Sosiaalinen aikakauskirja 1952, ss. $38-40$.

Sarvas, Marjatta, Perheenasuntoavustusjärjestelmä. Huoltaja I951, ss. 231-235.

Setälä, $T$., Tehostetumpi päivähuolto kotien avuksi. Lapsi ja nuoriso 1951: $7-8$, Ss. $20-22$.

Sihvonen, Kerttu, Perheenemännän taloudellinen ja yhteiskunnallinen asema. Emäntälehti 「951, ss. 18-21.

Siirtoväen sopeutuminen. Tutkimus Suomen karjalaisen siirtoväen sosiaalisesta sopeutumisesta. Kirj. Heikki Waris, Vieno Jyrkilä, Kyllikki Raitasuo \& Jouko Siipi. Helsinki 1952. 400 s. (Yhteiskunnallisen korkeakoulun julkaisuja 6).

Sillanpää, Miina, Aviottomasta äitiydestä. Lapsi ja nuoriso $1950: 4$, ss. $24-26$.

Simojoki, Martti, Kirkon kasvatusneuvontaa järjestämään. Vartija 1951, ss. 97-98.

Simonen, Aarre E., Asuntopolitiikkamme ajankohtaisia näköaloja. Sosiaalinen aikakauskirja 1951, ss. $240-256$.

- Ensi vuoden Arava-määrärahaa olisi korotettava 2 mrd. markalla. Suomen kunnallislehti $1951: 9$, ss. $9 \longrightarrow 11,30-31$.

- Kokonaisohjelma asiantuntijoiden käsiteltävänä. (Asuntopoliittista kokonaisohjelmaa koskeva keskustelu). Asuntopolitiikka 1951: 1, s. 4.

- Mitä Aravalla on saatu aikaan. Kansamme talous 195r, ss. 6-7.

Smeds, Helmer, Inrikesflyttningen i Finland 1878-1939. Reino Lento: Maassamuutto. Ekonomiska samfundets tidskrift 1952, ss. 28-37.

— Tillväxtriktningen för tätortsbefolkningen i Finland efter år 1920. Replik till dr Reino Lento. Ekonomiska samfundets tidskrift 1952, ss. $240 \longrightarrow 243$.

- Ar Finlands landsbygd överbefolkad? Nâgra synpunkter på flykten frân landsbygden och emigrationen. Ekonomiska samfundets tidskrift 1951, ss. $71-108$.

Sociallagstiftning och social verksamhet i Finland. Utg. av socialministeriet. Helsingfors 1951. $142 \mathrm{~s}$.

Sosiaalinen lainsäädäntö ja toiminta Suomessa. Sosiaaliministeriön julkaisema. Helsinki 1'350. $138 \mathrm{~s}$.

Stenbäck, A.: Triangeldramat i äktenskapsrådgivningen. Barn, familj, samhälie. Helsingfors 1952. Ss. $79-85$.

- Aktenskapskonflikterna och läkaren. Avioliitto ja lääkäri 1951: 1, ss. 13-14.

Strömmer, Aarno, Ammatti- ja elinkeinotilastomme perusteet vuoden 1950 väestölaskennassa. [1.] Tilastokatsauksia 1950: $7-8$, ss. $31-37$. [2.] Ks. Hyppölä, Jorma. 
- Asunnontarpeen tutkimuksesta. Asuntopolitiikka 1952:4, ss. 2-3, 6 .

- Väestökehityksen ja väestöpolitiikan näköaloja. Terveydenhoitolehti 1952, ss. $164-166$.

Stdhlberg, Aune, Katsaus viimeksi kuluneitten vuosien lastentarhatoimintaan. Huoltaja 1950, ss. $369-371$.

Suhonen Esko, Kokonaisohjelma asiantuntijoiden käsiteltävänä. (Asuntopoliittista kokonaisohjelmaa koskeva keskustelu). Asuntopolitilkka 1951: 1, S. 6.

- Yhteiskunnallisen tuen vaikutus asuntosuunnitteluun. Suomalainen Suomí 1951 , ss. $443-448$.

Sukselainen, V. J., Lapsilisäjärjestelmästämme. Kansamme talous 1951, s. 184.

- Mahtuuko perhekustannusten tasaaminien sosiaalisen huollon piiriin? Väestöliiton vuosikirja 3. Helsinki 1951. Ss. 7-14.

- Perhekustannusten tasaaminen. Porvoo-Helsinki 1950. 204 s, (Väestöpoliittisen tutkimuslaitoksen julkaisuja, sarja A 4.)

[Sulkunen, Paula], Perheenäidin vuosiloma. Kirj. P. S. Huoltaja 1952, ss. 337340.

Sumu, Aku, Keskustelua lapsilisäjärjestelmästä. Kansamme talous 1952, s. 618.

Suomen virallinen tilasto VI. Väestötilastoa A 103-106, B 102-106, C 101. Helsinki $1950-1952$.

Svartström; $N$., Lapsilisäjärjestelmästämme. Kansamme talous 1951, ss. 185-186. Svenska befolkningsförbundets i Finland publikation 11. Barn, familj, samhälle. Helsingfors 1952. $\mathrm{r} 30 \mathrm{~s}$.

Tamminen, Maisi, Osapäivätyö ja kotien tasapaino. Kansamme talous 1952, ss. $3-4$.

Tarasti, Aarne, Kodinhoitotoiminnan järjestelystä. Huoltaja 1951, ss. $67-71$.

- Kunnalliset kodinhoitajat. Maalaiskunta 1950, ss. 487-492.

- Laki kunnallisista kodinhoitajista. Sosiaalinen aikakauskirja 1950, ss. 339-347.

- Pohjoismainen sopimus lapsilisistä. Huoltaja 1951, ss. 385-386.

- Sosiaalihuollon lainsäädäntö. Sosiaalihuollon lakikokoelma. Helsinkí 1952. $304 \mathrm{~s}$.

Tarvainen, Lauri, Aviottomat lapset. Kätilölehti 1952, ss. 203-208.

- Vanhuuden pulma. Huoltaja 1951, ss. $123-126,391-394$.

Tio ār befolkningspolitik. Svenska befolkningsförbundets verksamhet $1942-52$. Barn, familj, samhälle. Helsingfors 1952. Ss. $118-126$.

Tirinen, Arvo, Aravan ohjelma v. 1951 ja sen toteutuminen. Suomen Kunnallislehti $1951: 6$, ss. 16-18.

- Aravan osuus maaseudun asuntotuotannossa. Maalaiskunta 1951, ss. 476-479.

- Aravan toiminta v. 1950. Sosiaalinen aikakauskirja 1951, ss. 20-25.

- Arava-tuotanto v. 1951. Sosiaalinen aikakauskirja 1952, ss. 293-298.

Tunkelo, A., Ennakkotiedot Suomen väkiluvusta 31. 12. 1950 väestölaskennan perusteella. Tilastokatsauksia 1951: $7-8$, ss. $33-35$.

- Havaintoja eduskunnan jäsenten ikävaihteluista Suomessa. Geron 2-3, ss. $3-9$. 
- Huomioita maalaiskuntien väkiluvun muutoksista vuosina 1940-1950. Maalaiskunta 1950 . Ss. $493-495$.

- Huomioita Tampereen väestön ikäryhmityksestä. Geron 2-3, ss. 39-43.

- Maaseudun väestökeskukset. Maalaiskunta 1950, ss. 323-327.

- Sota-avioliitat avioerotilaston valossa. Väestöliiton vuosikirja 3. Helsinki 1951. Ss. $105-118$.

- Väestölaskennan ennakkotietoja. Tilastokatsauksia 1952: $11-12$, ss. $49-52$.

- Väestötilastomme merkkivuosi. Kansanvalistusseuran kalenteri 1950, ss. 156160.

Tuominen, A. O., Maaseudun asuntojen tarve. Sosiaalinen aikakauskirja 1951, ss. $324-330$.

- Maaseudun asunto-olojen parantaminen. Maalaiskunta 1951, ss. 643-649.

Turunen, Aarno, Avioliittoneuvonnasta. Kätilölehti 1950, ss. 117-123.

Turunen, Sakari, Aviottomien lasten sairauksien vaikeusasteesta. Duodecim 1951, ss. $797-805$.

- Aviottomien lasten sairauksista. Duodecim 1951, ss. $789-795$.

- Sielullisesti poikkeavista aviottomista lapsista. Huoltaja 1951, ss. 11-13.

Tyррӧ, Sulo, Asuntokysymyksestämme. Kansamme talous 1952, ss. $328-329$.

Törnqvist, Leo, Finlands svenska befolkning i statistikens brännpunkt. Gunnar Fougstedt: Finlands svenska befolkning âren 1936-1945. Ekonomiska samfundets tidskrift $1952: 1$, ss. $37-39$.

Törnudd, Margit, Lastensuojelun uusia linjoja. Lapsi ja nuoriso 1951: 12, ss. $14-17$.

- Perhepäiväkodit - uusi lastensuojelun työmuotoko? Kirj. M. Tdd. Lapsi ja nuoriso $1950: 1$, ss. $3-4$.

Waismaa, Usko, Eräitä Englannin väestöpolitiikan saavutuksia ja tavoitteita. Väestöliiton vuosikirja 3 . Helsinki 1951. Ss. $164-173$.

- Huomioita lapsilisävalituksista. Huoltaja 1952, ss. 121-122.

- Keskustelua lapsilisäjärjestelmästä. Kansamme talous 1952 , ss. $616-6$ F .

- Kodinperustamislainat v. 1949. Sosiaalinen aikakauskirja 1950, ss. 135-137.

- Kodinperustamislainat v. 1950. Sosiaalinen aikakauskirja 1951, ss. 26-28.

- Kodinperustamislainat v. 1951. Sosiaalinen alkakauskirja 1952, ss. 37-38.

- Lapsilisät ja kansanavustus Isossa Britanniassa v. 1951. Sosiaalinen aikakauskirja 1952, s. 494.

- Pohjoismainen sopimus lapsiavustuksen vastavuoroisesta suorittamisesta. Sosiaalinen aikakauskirja 1952, ss. 390-392.

Valanne, Kirsti, Miten äidin työssäolo vaikuttaa lapseen? Lapsi ja nuoriso 1951:9, ss. $19-24$.

Valanne, Kirsti \& Valanne, Eero H., Perhekeskeisen sosiaalityöntekijän osuudesta kasvatusneuvonnassa. Kätilölehti 1952, ss. 275-280.

Valvanne, Leena, Abortintorjuntaa Ruotsissa ja Tanskassa. Avioliitto ja lääkäri 1952: 4 , ss. $10-11$. 
- Syntyvyyden säännöstelyn sosiaalisesta ja terveydellisestä taustasta Suomessa. Väestöliiton avioliittoneuvolan kirjeenvaihtoon vv. 1948-1949 perustuva tutkielma. Väestöliiton vuosikirja 3. Helsinki 1951. Ss. 133-144.

- Työstä raskauden vuoksi vaikeuksiin joutuneiden hyväksi. Sasiaalineuvolan syntyvaiheet. Sairaanhoitajalehti 1950 , ss. $17-19$.

Waris, Heikki, Armas Nieminen: Taistelu sukupuolimoraalista. Historiallinen aikakauskirja 1951 , ss. $257-261$.

- Armas Nieminen: Taistelu sukupuolimoraalista. Suomalainen Suomi 1952, ss. $41-42$.

- Axel von Gadolin: Das Flüchtlingsproblem in Finnland. Kansantaloudellinen aikakauskirja 1952, ss. $131-133$.

- Ihminen ja muuttuva yhteiskunta. Huoltaja 1952, ss. 195-199.

- Murrosajan yhteiskuntamme. Suomalainen Suomi 1950, ss. $327-332$.

- Sosiaalisen tasauksen pyrkimys. Suomalainen Suomi 1951, ss, $453-459$.

- Suomalaisen yhteiskunnan rakenne. 2. p. Helsinki 1952. 368 s.

Wickström, Johan, Nàgra synpunkter på văr skärgărdsbefolkning. Barn, familj, samhälle. Helsingfors 1952 . Ss. 86-98.

Wickström, Kristina, Familjen och anstalten som uppväxtmiljö. Barn, familj, samhälle. Helsingfors 1952. Ss. 40-48.

Widgren, Kalle, Kehittyvä kaupunki - kehittyvä lastensuojelu. Lapsi ja nuoriso 1950: $7-8$, ss. $5-6$.

Virtanen, Helge, Suomalaisen yhteiskunnan sosiaalipolitiikka. Jyväskylä 1950. $200 \mathrm{~s}$.

Vuokko, Eila, Miksi äiti ei jää kotiin. Tulevaisuus $1952: 12$, ss. $12-13,42-43$.

Vuoristo, Gunnar, Kasvatusneuvoloiden osuus avioliitossa esiintyvien ongelmien selvittämisessä. Avioliitto ja lääkäri 1951: 2, ss. 5-6.

Vuoristo, Gunvor, Entä isän vastuu kodin hengestä? Lapsi ja nuoriso 1952: 6, ss. $21-23$.

Vardlagarna. Samlade av socialministeriet. Helsingfors 1950. $290 \mathrm{~s}$.

Väestöliiton julkaisuja 26. Perhelisätarvikkeita 1950. Ohjekirjasen "Perhelisälain toimeenpano" lisälehti n:o 8. Helsinki 1949. 18 s.

- 27. Toukokuun toinen sunnuntai. Helsinki 1950. $32 \mathrm{~s}$.

- 28. Perhelisätarvikkeet v. 1951. Helsinki 1950. 8 s.

- 29. Kaprio, Leo A., Syntyvyyden säännöstely. Helsinki 1951. 15 s.

- 30. Toukokuun toinen sunnuntai. Helsinki 1952. $32 \mathrm{~s}$.

- 31. Vihdoinkin vapaaksi veroluokista. (Kulutusyksikköverotuksesta). Helsinki 1952. $4 \mathrm{~s}$.

Väestölititon vuosikirja 3 . Väestönkehityksen ja avioliiton ongelmia. Helsinki 1951. $225 \mathrm{~s}$.

Väestölititto. Huoltaja 1950, ss. $229-233$.

Väestöpoliittisen tutkimuslaitoksen julkaisuja. Sarja A: 4. Sukselainen, V. J., Perhekustannusten tasaaminen. Porvoo-Helsinki 1950. 204 s. 
- A 5. Lento, Reino, Maassamuutto ja sihen vaikuttaneet tekijät Suomessa vuosina 1878-1939. Helsinki 1951. $251 \mathrm{~s}$.

- A 6. Nieminen, Armas, Taistelu sukupuolimoraalista. Porvoo-Helsinki 1951. $410 \mathrm{~s}$.

Väisänen, Paavo, Maaseudun asunto-olojen parantamistoiminnasta Ruotsissa. Asutustoiminnan aikakauslehti $1950: 3$, ss. $7-9$.

Väänänen, Pirkko, Vanhuuden ongelmista. Avioliitto ja lääkäri 1952: 2, ss. 5-6.

Väätäjä, Alpo, Kunnanlääkärin näkemyksiä äitiyshuoltotyöstä ja sen kehittämismahdollisuuksista. Kätilölehti 1951, ss. 215-219.

Yliruokanen, Aino, Välähdyksiä äitiys- ja lastenhuollon kenttätyöstä Intiassa. - Sairaanhoitajalehti 1952 , ss. $294-295,297-8,342-345$.

Aidin kalenteri 1951, 1952 ja 1953. Julk. Väestöliitto. Helsinki 1950, 1951 ja 1952. Aitiysavustukset v. 1948. Sosiaalinen aikakauskirja 1950, ss. $133-135$.

- v. 1949. Sosiaalinen aikakauskirja 1951, ss. 106-107.

- v. 1950. Sosiaalinen aikakauskirja 1952, ss. $40-41$.

Östenson, Ebba, Mödrar i förvärvsarbete. Barn, familj, samhälle. Helsingfors 1952. Ss. $34-39$. 